\title{
Shape matters: relevance of carapace for brachyuran crab invaders
}

\author{
Marc Farré · Antoni Lombarte · Víctor M. Tuset · Pere Abelló
}

\author{
M. Farré · A. Lombarte · V.M. Tuset · P. Abelló \\ Institut de Ciències del Mar (ICM-CSIC), Passeig Marítim de la Barceloneta, 37-49, \\ 08003, Barcelona, Catalonia, Spain
}

\section{Corresponding author:}

Marc Farré, e-mail: farre@,icm.csic.es, telephone number: +34 932309555, ORCID: 0000-0002$2263-4800$

Antoni Lombarte ORCID: 0000-0001-5215-4587

Víctor M. Tuset ORCID: 0000-0001-9032-2844

Pere Abelló ORCID: 0000-0001-6034-2465

\section{Acknowledgements}

Authors want to acknowledge the staff of the Biological Reference Collections (CBR) of the Institut de Ciències del Mar (ICM-CSIC) of Barcelona (Francisco J. Olivas and Ricardo Santos) for their help in the identification, separation and transferring of the samples used in the present study. 


\section{Abstract}

2 The increasing trend of biological invasions is one of the most concerning threats for ecosystems

3 functioning. The identification of optimal characters determining the invasive potential of non-

4 native species has always been a challenge in conservation studies. Morphological features can

5 be used as a good proxy to address the invasive success in fish species, assuming that anatomical

6 differences in comparison to native species can provide to newcomers ecological opportunities

7 increasing their probability to become successful. Considering this, the present study constitutes

8 the first applicative attempt of a model based on geometric morphometrics to demonstrate the

9 importance of the carapace shape in the invasive ability in marine decapod crustaceans. The study

10 was performed on the native brachyuran community of Alfacs Bay, in the Ebro Delta, the largest

11 estuarine zone along the north-western Mediterranean, in which two recently established non-

12 native crab species coexist: Dyspanopeus sayi and Callinectes sapidus. Results suggested that

13 invaders with extreme carapace traits located peripherally in the community morphospace, such

14 as C. sapidus, usually possess ecological advantages contributing to understand their success.

15 Conversely, intermediate morphologies within the morphospace, such as D. sayi, imply ecological overlapping with native species reducing their community relevance. Besides, we also assessed the effect on the community morphospace of a hypothetical future invasive event from another crab species (Portunus segnis) with high probabilities to also colonize the community.

19 Our outcomes confirm that the morphometric approach could be an alternative tool for assessing 20 the potential ability of invasive crab species. However, further studies at different spatial and 21 temporal scales, including additional traits and quantitative data from invasions, would be 22 necessary to confirm the efficacy and usefulness of the methodology. 
25 Keywords

26 Invasive crabs $\cdot$ Carapace shape $\cdot$ Geometric morphometric analysis $\cdot$ Morphospace $\cdot$ Ecological

27 competition $\cdot$ Estuarine community

28

29

30

31

32

33

34

35

36

37

38

39

40

41

42

43

44

45

46

47

48 
51 Within the current broadly accepted context of global change, multiple human-associated phenomena altering marine ecosystems at different levels of organization have already been identified (Harley et al. 2006; Halpern et al. 2008; Hoegh-Guldberg and Bruno 2010). Direct (e.g., fishing overexploitation, pollution or habitat loss) and indirect (e.g., global warming, ocean acidification or transport of ballast water) anthropogenic activities are intensively affecting the dynamics of biological communities, causing shifts in geographical distribution range and

57

58

59

60

61

62

63

64

65

66

67

68

69

70

71 abundance of species (Parmesan and Yohe 2003; Perry et al. 2005; González et al. 2017) and changes in population dynamics of species affecting their recruitment, dispersion and performance at different life stages (Cury et al. 2008; Pörtner and Farrell 2008; Hidalgo et al. 2011) or in the biodiversity and structure of communities (Hughes et al. 2003; Philippart et al. 2011; Wernberg et al. 2013). However, one of the most concerning events, both for the scientific community and society, is the occurrence and establishment of alien invasive species in native communities, due to its impact on the ecosystem functioning and by their potential economic and ecological costs on ecosystem services (Harris and Tyrrell 2001; Stachowicz et al. 2002; Karatayev et al. 2009; Katsanevakis et al. 2014). Most studies related with the effects of biological invasions have been focused on the assessment of their ecological consequences on native communities (Grosholz 2002; Simberloff et al. 2013) or in the understanding of causes, vectors, pathways and mechanisms of invasive processes (including introduction, colonization, establishment and spread, see Walther et al. 2009) in order to, at larger extent, identify the optimal and common traits of successful invaders and attempt to predict their invasive potential (Kolar and Lodge 2001; Ficetola et al. 2007). 
In the Mediterranean Sea, there are up to 45 different known species of allocthonous brachyuran crabs (Galil et al. 2002; Galil 2011), most of them inhabiting the benthic or demersal domain from sublittoral, littoral and estuarine zones, areas especially susceptible to biological invasions due to their high productivity and strong physicochemical fluctuations (Grosholz 2002; Lejeusne et al. 2014). Among them, some of the most common and better established in the western Mediterranean are native from western Atlantic waters, as the case of the American blue crab Callinectes sapidus (Rathbun, 1896) (with first reports detected in 2012 in the Ebro Delta, Castejón and Guerao 2013), and the Say mud crab Dyspanopeus sayi (Smith, 1869) (first record in 2005 in the Ebro Delta, Schubart et al. 2012). Both are euryhaline and eurythermal species native from the western Atlantic Ocean inhabiting shallow estuaries and coastal lagoons (Williams 1984; Nizinski 2003; Nehring 2011). They expanded eastwards probably through human-induced actions and they are currently widely expanded along the eastern Atlantic and most of the Mediterranean Sea (Froglia and Speranza 1993; Micu et al. 2010; Nehring 2011). Especially worrisome is the case of C. sapidus, since its wide environmental tolerance and adaptation, aggressive competition for resources, large size, high fecundity rates and large dispersal capacity (Hill et al. 1989; Nehring 2011; Mancinelli et al. 2013) turn him a successful invader representing a serious threat for native ecosystems. In fact, presently it is already considered one of the 100 'Worst Invasive Alien species in the Mediterranean' (Streftaris and Zenetos 2006). However, most of the invader species in the Mediterranean are native from tropical areas of the Indo-Pacific Ocean and Red Sea, which have entered through the Suez Canal. The most highlighting case is the blue swimming crab Portunus segnis (Forskål, 1775), another portunoid crab with similar invasive behavior than C. sapidus that recently showed a dramatic increase in abundance in the southern central Mediterranean (Gulf of Gabes, Tunisia, Crocetta et al. 2015). It inhabits sandy-muddy and seagrass bottoms of coastal and intertidal areas 
and is native from the western Indian Ocean, Persian Gulf and Red Sea (Lai et al. 2010; Rabaoui et al. 2015). It is considered one of the earliest alien crabs identified in the Mediterranean (Galil 2011) and its current distribution comprises the southern shores of the eastern and central Mediterranean. P. segnis is an opportunistic benthic carnivore species with high competitive ability and a great invasive potential given its efficient and fast reproductive and growth ability (Pazooki et al. 2012; Safaie et al. 2013; Rabaoui et al. 2015) that would probably produce important impacts in the structure of local communities. Considering the state of biodiversity change that the Mediterranean Sea is experiencing in the last decades (Galil 2007; Katsanevakis et al. 2014), it could be expected that this species would show a large process of geographical expansion.

In brachyuran crabs, the presence of specific morphological features (e.g., spines, stronger carapaces, efficient claws or adapted appendages) are common in many invasive species since they influence positively their successful performance within native communities (Hartnoll 1971; Lee 1995; Weis 2010; Daly et al. 2020). According to this, the main goal of the present study is to determine the degree of morphological variability of the carapace shape of brachyuran crab invaders in relation to native species from the local littoral community of Alfacs Bay, in the Ebro Delta (NW Mediterranean). We selected this brachyuran community because it is well-known for decades (Fusté 1988) and because is affected by two invader currently well-established species (C. sapidus and D. sayi). Our initial hypothesis is that brachyuran invaders with uncommon carapace shapes may possess certain ecological advantages in some essential life-history habits (such as physiological adaptations to environment, reproduction efficiency, habitat use or predator avoidance) as occurs in fishes with body shape (Azzurro et al. 2014; Smith et al. 2016; Rojas-Vélez et al. 2019). Additionally, a hypothetical future scenario of entrance of a not yet detected new invasive species in the study area, but already abundant in relatively nearby areas 
120 (P. segnis) was also analyzed. Thus, the present study represents the first attempt to apply a 121 morphological methodology to explore the potential invasive ability in marine decapod 122 crustaceans.

Materials and methods

Study area and native crab community

The selected community of study was the brachyuran community inhabiting between $0-1 \mathrm{~m}$ in the Alfacs Bay, a semi-enclosed estuary of $3 \mathrm{~m}$ mean depth at the south side of the Ebro Delta region (NW Mediterranean), which is isolated from the open sea by a sandbar of $5 \mathrm{~km}$ long and $300 \mathrm{~m}$ wide (Fig. 1). This bay is mainly formed by sandy, muddy bottoms and seagrass meadows and receives freshwater from early spring to autumn through discharge channels that flow out from its northern extreme (Camp and Delgado 1987; Solé et al. 2009). Given its estuarine and brackish conditions, this area has been the object of several crab invasions during the last decades (Schubart et al. 2012; Castejón and Guerao 2013), this being the main reason why this location and faunistc assemblage were selected for the present study.

137 The specific composition of the native crab community was extracted from Fusté (1988), who 138 studied monthly the decapod fauna from the bay during two years (march 1984-1986) using two 139 different gears, traditionally used by the local artisanal fleet (trammel nets and 'rastell' bottom140 towed dredges, Fusté 1988) over sandy and muddy bottoms of about 0-1 m depth. A total of 19 141 crab species belonging to 13 superfamilies were identified and considered as the native or base142 line community (Table 1). Unfortunately, since then no additional similar samplings have been 143 performed to determine the composition of the crab assemblage of this area. However, personal 
communications with local fisheries administration and fishermen suggest that changes on composition do not seem to be noticeable, and therefore it was considered the assemblage defined by Fusté (1988) as representative of the current crab assemblage.

\section{Carapace shape characterization and morphospace construction}

The morphological description was performed using landmark-based geometric morphomterics. The specimens used for the present study were obtained from the Biological Reference Collections (CBR, http://cbr.icm.csic.es) of the Institute of Marine Sciences of Barcelona (ICM). Due to the noticeable sexual and ontogenetic dimorphism that crabs present in their general body shape (Rufino et al. 2004; Alencar et al. 2014), as well as for the higher availability of male specimens for most of species, only adult males were analyzed in the present study in order to avoid bias during the comparative shape analysis (Table 1). The initial intention was to include the measurement of both carapace and other appendages (claws and pleopods) shape. However, given the fragility of appendages and the state of conservation of the specimens, in many cases they were incomplete and lacked of the claws, pleopods or both. Thus, in order to avoid bias along the comparative morphometric process, we decided to discard both type of appendages from the study and only describe the carapace shape. Firstly, each specimen was photographed in dorsal view in standardized and scaled positions. The scheme of landmarks (fixed homologous points) and semilandmarks (sliding or mobile non-homologous points), consisting in 10 different points defining the general dorsal carapace shape (Fig. 2), was selected based on commonly used configurations in previous morphometric studies with the aim of capturing the maximum of body shape information (a detailed description of the meaning of landmarks and semilandmarks and the used bibliography is provided in Supplementary material, Table S1). In order to avoid 
duplication of equivalent landmarks in symmetrical structures (as is the case of the crabs carapaces) that causes computation distortions during the analytical process, only one side of the carapace was considered in the definition of landmarks (Rohlf and Slice 1990; Rufino et al. 2004, 2006).

The digitalization of landmarks and semilandmarks in all male specimens of each species was performed using tpsDig v. 2.30 (Rohlf 2017a). Then, assuming that intraspecific variability is lower than interspecific morphological variability, we obtained a consensus configuration for each species that were used as the mean shape of each species in the remaining analyses. In order to remove scale, orientation and size distortions not related with shape, a generalized Procrustes analysis (GPA) was applied using tpsRelw v. 1.69 (Rohlf 2017b), which translates all configurations to a common centroid position in the coordinate system, scales them to unit centroid size and rotates them to minimise the distances between corresponding landmarks (Adams et al. 2004; Zelditch et al. 2012). Initially, GPA coordinates are not expressed within an Euclidean space shape. To project these Procrustes coordinates in a tangent space and test whether shape variation is small enough to consider this new space a good image of the Euclidean space (Rohlf 1999), we computed the correlation between the tangent and Procrustes distances using tpsSmall v. 1.34 (Rohlf 2017c). The results of correlation (uncentered correlation $=0.999933$, root mean square error $=0.000501$ ) confirmed that both spaces were nearly identical for our data.

GPA also generates the uniform components of the shape variation for each analyzed object (relative warps, RWs) by applying the thin-plate spline procedure, which creates a consensus configuration by averaging the coordinates of all the landmarks. Each relative warp represents a specific set of morphological characteristics, allowing to visualize the changes in shape between species (Zelditch et al. 2012; Farré et al. 2016). The scores of the first two warps, which reached 
more than $85 \%$ of the total morphological variation, were used to plot the morphological position of each species in a two-dimensional graphic (morphospace) using PAST software v. 3.16

194 (Hammer et al. 2001).

Morphological variability analysis

197

The morphological dissimilarity within the morphospace of the community was computed from methods based on the position of all species in the native morphospace and the distances between them. Specifically, four variables were estimated: a) the convex hull, which was used to measure the total dimension and shape of the assemblage morphospace and for further analyses. It is defined as the smallest space enclosing all the individuals of a group (e.g, species of a community or specimens of a species, Cornwell et al. 2006) and was computed in two different ways: at specific level, in order to group by species and determine the intraspecific morphological variability for each species within the morphospace, and at community level (obtained using the consensus configuration of each species, see morphospace construction section) for the later computation of Voronoi polygons. In both cases, it was built using Delone software v. 1.0.1.19; b) the nearest-neighbour Euclidean distances (NND) between all the species within the morphospace, which identify their 'closest' neighbours (Smith et al. 2016) and measure the distances between them, and that were obtained using the package spatstat v. 1.59 (Baddeley et al. 2015) in R (R Development Core Team 2017); c) the configuration and area of Voronoi

212 polygons (VOR), a tessellation method determined by distances among species in the space that 213 creates polygons enclosing the area belonging to each species (Du et al. 2012), which were 214 estimated using Image-Pro Plus, v. 5.0.0.39 software (Media Cybernetics, Inc.). Voronoi 215 polygons were created from the convex hull of the overall community morphospace obtained 
216 from the consensus configuration of each species. The position within the community 217 morphospace and the size of the Voronoi cells can be explanatory of the available "niche 218 opportunities' for species within a community (Azzurro et al. 2014; Smith et al. 2016); and 219 finally d) the morphological disparity (MD), which measured the intraspecific morphological 220 variation among species (Zelditch et al. 2012) and that was obtained with the package geomorph 221 (Adams et al., 2020) in R (R Development Core Team 2017).

222 In order to characterize and assess the temporal evolution of the crab community morphospace until present time, as well as consider possible future scenarios of hypothetical new invasions, the 224 morphospace representation and the estimation of all variables (convex hull, VOR, NND and 225 MD) were computed at three different temporal moments: 1) considering the native crab 226 community (NCC) described by Fusté (1988); 2) including the non-native but currently 227 established species $D$. sayi and C. sapidus to the native community (current crab community, $228 \mathrm{CCC}$ ); and 3) considering the hypothetical future entrance of $P$. segnis to the current crab 229 community, thus imagining a potential future crab community (FCC). Assuming that the three 230 scenarios are temporally consecutive, changes in the morphospace structures and dissimilarity 231 measures were only compared (as shifts in magnitude) with respect to the previous time period.

\section{Results}

234

235 Morphospace configurations evidenced morphological variability along the crab communities 236 (Fig. 3a-c). Species segregated along the $x$ axis (RW1, 70.3\% of total variance) based on the 237 general carapace shape (total width and antero-posterior elongation). In the positive extreme were 238 found species with antero-posteriorly elongated and laterally compressed carapaces, with shorter 239 postero-lateral margins (Macropodia spp., Parthenopoides massena, Corystes cassivelaunus), 
whereas in the negative extreme were located species with wider and antero-posteriorly shorter carapaces as well as longer postero-lateral margins (Goneplax rhomboides, C. sapidus, $P$. segnis). In contrast, throughout the $y$ axis (RW2, 15.8\% of total variation) species spread according to the relation between the size of the anterior and posterior regions of the carapace. The negative side was occupied by species with anterior and posterior regions of similar sizes $(C$. cassivelaunus, Atelecyclus rotundatus, Ilia nucleus), while in the positive side were placed species with anterior regions more developed than posterior regions (C. sapidus, P. segnis, Calappa granulata, Medorippe lanata).

The morphospace and convex hull of the native community (NCC, Fig. 3a) was markedly modified by the extremely outside location, oversteping the native limits, of $C$. sapidus (CCC, Fig. 3b). Its particular carapace shape led the species to occupy a relatively large morphospace portion away from the closest species, Xantho poressa (Table 1). Nevertheless, it located relatively near from the core of hexagonal shapes, being one of the species that showed higher intraspecific phenotypic variation (Table 1). By contrast, D. sayi showed a similar morphology to some portunoid, grapsoid and xanthoid native species (Liocarcinus spp., Necora puber, Carcinus aestuarii, Brachynotus sexdentatus, $X$. poressa) and thus located close to these native species more centrally inside the convex hull of the morphospace, taking up less space and supplying little morphological disparity in relation to closer species (Fig. 3b, Table 1).

Finally, in the future hypothetical scenario of new invasion in the current community (FCC), the potential invader $P$. segnis presented a strong carapace shape similarity with $C$. sapidus although not so extreme, locating inside the limits of the convex hull (Fig. 3c). The shape resemblance with the currently established invader caused that presented low morphological disparity (Table 1). However, its specific location allowed him to acquire a high VOR value (Fig 
3c, Table 1), noticeably affecting to the occupied space by their surrounding species ( $G$. rhomboides, Pilumnus spinifer, $X$. poressa and especially C. sapidus).

\section{Discussion}

The present study analyzed the carapace morphological variability of a local brachyuran crab assemblage of the Ebro delta, one of the largest estuarine zones of the Mediterranean Sea (Camp and Delgado 1987; Guillén and Palanques 1997), affected by the invasion of several non-native species. Our findings revealed a large interspecific diversity of carapace shapes for the native species, including pyriform (Macropodia spp.), triangular (P. massena), circular (I. nucleus, A. rotundatus), longitudinally ovate (C. cassivelaunus, Maja crispata), transversely ovate (X. poressa), subovate (C. granulata), pentagonal (M. lanata), squarish ( $G$. rhomboides) and a majority of hexagonal (Liocarcinus spp., B. sexdentatus, C. aestuarii, N. puber) shapes (following the terminology described by $\mathrm{Ng}$ 1998). Instead, the non-native species $D$. sayi possesses a carapace with an intermediate shape between transversely ovate and common hexagonal, whereas the invader $C$. sapidus presents an exclusive transversely hexagonal shape characterized by extremely lengthened lateral spines. These phenotypes allowed them positioning in different zones of the native morphospace: while $D$. sayi was noted within the morphospace close to other native species, $C$. sapidus expanded the original limits of the morphospace and was located in the periphery, distant from the nearest native species, occupying an 'empty' zone. This dissimilarity in carapace shape showed by the newcomers coincides with ecological theories supporting that successful invaders usually possess noticeable differences in many life-history (including morphological) traits when compared with native species that allow them to reduce, avoid or overcome competition with residents (Shea and Chesson 2002; Catford et al. 2009; Weis 
2010; Parravicini et al. 2015). Carapace shape is recognized as an important trait in defining ecological and biological habits of crab species related with reproductive, physiological, habitat or behavioral strategies (Rufino et al. 2004; Silva et al. 2009; Olesen 2013). For instance, its variability can be illustrative of strategies of sheltering and predator avoidance, determining refuge preferences on rocky shores and salt marsh habitats (Idaszkin et al. 2013) or the burrowing and burying ability of crabs in soft bottoms, since excavating mechanics, depth of concealment and associated physiological adaptations are usually related with the carapace shape (Taylor and Atkinson 1991; Bellwood 2002; Veas et al. 2014). Also the presence of spination over and around the carapace margins is identified as an anti-predator adaptation (Davie et al. 2015; Daly et al. 2020).

The real magnitude of success of crab invasive processes importantly depends on many other factors beyond the carapace morphology of species related with, among others, the ecological, biological and behavioural adaptability of non-native species (e.g., body size, agressivennes, competition degree, larval lifespan and dispersion, physiological tolerance) and with the abiotic and biotic environmental conditions (e.g., presence of predators, pathogens, interactions and resistance with native species) of the receiving ecosystem (Catford et al 2009; Weis 2010; Ricciardi et al 2013). Nevertheless, diverse studies suggest that non-native species locating in peripheral positions within morphospaces, such as C. sapidus, tend to be highly successful or top invaders (Azzurro et al. 2014; Smith et al. 2016; Rojas-Vélez et al. 2019; Tuset et al. 2020). Considering the high invasive potential of C. sapidus, which has led the species to colonize practically the entire Mediterranean basin (Galil et al. 2002; Streftaris and Zenetos 2006), including the study area (López and Rodon 2018), it is reasonable to assume that its particular carapace shape (completely disimilar to the remainig species) could also partially contribute, among many other factors, to its successful performance for several reasons: a) the over- 
development of the anterior part of the carapace (noted by the considerable expansion in $y$ axis) entails a widening of the branchial region and antero-lateral margin. This would allow an enlargement of the gill chambers and surface, improving thus its respiratory efficiency (Millikin and Williams 1984; DeFur et al. 1988) and the capability to avoid desiccation by assuring more water conservation (Hopkins and Thurman 2010; Hampton et al. 2014); b) its large-sized stout, thick and flattened carapace characterized by strong spines along the antero-lateral margin finishing with especially lengthened lateral spines (Pyle and Cronin 1950; Millikin and Williams 1984) would act as a defensive adaptation against predators, even providing advantages over native competitors (Davis et al. 2004; Young et al. 2008); or c) this wider-shaped carapace would also contribute to the reproductive efficiency, providing females with a larger surface and volume for carrying and brooding fertilized eggs and favoring high fecundity rates (Van Engel 1958; Prager et al. 1990; Jivoff et al. 2007; Darnell et al. 2009). Instead, the intermediate positioning of D. sayi within the morphospace may indicate a higher ecological overlap, and thus direct competition, with the morphologically close native residents. Its carapace shape, between hexagonal and transversely ovate, can be considered a strategical advantage for occupying tridimensional complex habitats (Williams 1984; Micu et al. 2010, Cabiddu et al. 2020). In fact, the species is able to coexist with species typically from sandy and muddy bottoms (Liocarcinus spp., B. sexdentatus, C. aestuarii, Froglia and Speranza 1993; Mistri 2004) as well as with species over boulders and cobbles in fragmented rocky shores (X. poressa, Reuschel and Schubart 2007; Spivak et al. 2010). This high habitat adaptability of the species can help to understand its colonization along almost the whole Mediterranean Sea (Froglia and Speranza 1993; Mizzan 1995; Micu et al. 2010; Schubart et al. 2012; Thessalou-Legaki et al. 2012; Ulman et al. 2017). However, when habitat complexity is more reduced, given its small size and that it rarely buries, this species can be preyed by larger-sized species such as C. aestuarii (Gehrels et 
al. 2016). This higher vulnerability to predation, together with the interspecific competition that would have to confront with morphologically-close species, would support that the species, despite its expansive and establishment ability, show a lower invasive potential than C. sapidus. Following the same premises, results suggest that $P$. segnis might also be a top invader since its morphological similarity in carapace shape with C. sapidus provides it with a similar ecological and biological performance (Safaie et al. 2013; Crocetta et al. 2015; Rabaoui et al. 2015). Here the interest would lie in assessing the result of its probable direct competition with the closer residents especially with $C$. sapidus, since it would probably exercise resistance limiting the entrance of the newcomer, as occurred in experiments between C. sapidus and Carcinus maenas (DeRivera et al. 2005). In any case, given that the direct competence would affect all species, it would be plausible that $P$. segnis could stand competence and coexist with the previously established species (MacDonald et al. 2007), and therefore become a invader with a high probability to establish within the community (Katsanevakis et al. 2014).

Brachyuran crabs are the most numerous and diverse group of decapods occupying a wide spectrum of ecological niches and lifestyles (Davie et al. 2015) and their particular crab-shape and high phenotypic variability have always been considered as fundamental to explain their great diversity and evolutionary success (Števčić 1971; Förster 1985; Scholtz 2014). The local crab community analyzed in the present study represents a good illustrative example of this morphological diversification, showing a broad range of different carapace shapes and some redundancy of hexagonal shapes characteristic from portunoid (Liocarcinus spp, C. aestuarii, $N$. puber), grapsoid (B. sexdentatus) or pilumnoid (P. spinifer) species. Considering that under particular environmental conditions the selection towards certain specialized phenotypes that maximize the ecological efficiency of species is common (environmental filtering hypothesis, Zobel 1997), this carapace shape (similar to that of invader species) could be interpreted as an 
optimal trait for the specific studied area. Therefore, the entrance of newcomers (including the future hypothetical case) would probably entail negative effects, at greater or lesser extent, to these native species with similar morphologies by increasing competence and reducing their ecological niche. On the other hand, native species with higher phenotypic variability (e.g., Liocarcinus depurator or $X$. poressa) could exhibit a higher resilience to the perturbations caused by the invasive processes (Allen and Holling 2010; Berthon 2015). In any case, the occurrence of invader species will produce certain degree of alteration in the structure and functioning of the native assemblage. However, it is difficult to identify and quantify the real specific impacts that invaders would cause to native residents considering only the carapace shape as niche trait and with no abundance data from the community. A more complete definition of the ecological niche of the community would be necessary to unravel the real effects of invaders on the residents, which would require considering other morphological features (e.g., body size, size and shape of claws or presence of transformed appendages such as flattened paddle-like swimming pleopods and pereiopods) essential by habits such as with foraging, locomotion, defensive, aggressiveness, competitive and mating strategies of crabs (Hartnoll 1971; Vermeij1977; Hines 1982; Lee 1995; Sneddon et al. 1997; Mariappan et al. 2000). Unfortunately, the measuring of some of these structures (claws and pleopods) could not be included in the present study due to methodological difficulties, entailing evident limitations for the ecological interpretations of the study, and thus are effusively encouraged to be included in further studies.

In conclusion, the present study represents a first attempt to evaluate the potential effects of the entrance of marine crustacean alien species (brachyuran decapods) within native assemblages using a methodological approach based on the analysis of external morphology of species, currently only applied in fishes both for body shape (Azzurro et al. 2014; Smith et al. 2016; Rojas-Vélez et al. 2019) or for sensory structures such as otoliths (Tuset et al. 2020). The study 
was performed in a local specific community, including a relatively small sampling size and from a very enclosed environment in terms of spatial and temporal coverage, which entails evident limitations. Further studies at larger spatial and temporal scales, including larger sets of species that encompass higher ecological and functional variability, should be performed in order to more robustly contrast the efficacy of this model in decapod crustaceans. Besides, a more complete morphological description including other anatomical structures of ecological interest such as claws and other appendages (Hartnoll 1971; Vermeij 1977; Lee 1995, Davie et al. 2015), would be necessary for a more deeply assessment of the ecological conclusions from the morphospace results. However, results based on carapace shape, a morphological trait also strongly related with the ecological performance of species, suggest that invaders that present differential morphological traits can possess ecological advantages that would increase their likelihood to establish themselves since they avoid competition with similar residents. The study demonstrates that this straightforward morphometric protocol can be employed as an alternative effective tool to preliminary assess the effects of invasive processes of species from different taxa and phyla as well as when ecological data of invader species is scarce. Notwithstanding, it should be complemented by studies incorporating accurate quantitative ecological information of the invasive events to extract more robust conclusions about the evolution of invasive species within native communities.

401

\section{Author's contribution}

403 All authors contributed to the study conception and design. MF and PA selected and prepared 404 samples for the study; MF and AL performed the morphological analyses; VMT performed some 405 of the statistical analyses; all authors interpreted data. MF and VMT wrote the first draft of the 
manuscript. All authors commented on previous versions of the manuscript and approved the

407 final manuscript.

408

409

\section{Funding}

410 The present study is included and financed within the framework of the project CLIFISH (CTM2015-66400-C3-3-R, MINECO/FEDER), funded by the Spanish Ministry of Economy and Competitiveness and by the European Regional Development Fund (ERDF).

\section{Compliance with Ethical Standards}

\section{Conflict of interest}

416 The authors declare that they have no conflict of interest.

\section{Ethical approval}

418 All the research was performed following the general guidelines for the ethical use of animals.

\section{References}

421

422

Adams DC, Collyer M, Kaliontzopoulou A (2020) Geometric Morphometric Analyses of 2D/3D geomorph.pdf

Adams DC, Rohlf FJ, Slice DE (2004) Geometric morphometrics: ten years of progress following the "revolution." Ital J Zool 71:5-16

Alencar CERD, Lima-Filho PA, Molina WF, Freire FAM (2014) Sexual shape dimorphism of the mangrove crab Ucides cordatus (Linnaeus, 1763) (Decapoda, Ucididae) accessed through geometric morphometric. Sci World J 2014:206168. doi: 10.1155/2014/206168

Allen CR, Holling CS (2010) Novelty, Adaptive Capacity, and Resilience. Ecol Soc 15:24

Azzurro E, Tuset VM, Lombarte A, Maynou F, Simberloff D, Rodríguez-Pérez A, Solé RV 
(2014) External morphology explains the success of biological invasions. Ecol Lett 17:1455-1463. doi: 10.1111/ele.12351

Baddeley A, Rubak E, Turner R (2015) Spatial Point Patterns: Methodology and Applications with R. London: Chapman and Hall/CRC Press, 2015. http://www.crcpress.com/SpatialPoint-Patterns-Methodology-and-Applications-with-R/Baddeley-RubakTurner/9781482210200/

Bellwood O (2002) The occurrence, mechanics and significance of burying behaviour in crabs (Crustacea: Brachyura). J Nat Hist 36:1223-1238. doi: 10.1080/00222930110048891

Berthon K (2015) How do native species respond to invaders? Mechanistic and trait-based perspectives. Biol Invasions 17:2199-2211. doi: 10.1007/s10530-015-0874-7

Cabiddu S, Addis P, Palmas F, Pusceddu A (2020) First record of Dyspanopeus sayi (Smith, 1869) (decapoda: Brachyura: Panopeidae) in a Sardinian coastal lagoon (western mediterranean, Italy). BioInvasions Rec 9:74-82. doi: 10.3391/bir.2020.9.1.10

Camp J, Delgado M (1987) Hidrografía de las bahías del Delta del Ebro. Investig Pesq 51:351359

Castejón D, Guerao G (2013) A new record of the American blue crab, Callinectes sapidus Rathbun, 1896 (Decapoda: Brachyura: Portunidae), from the Mediterranean coast of the Iberian Peninsula. Bioinvasions Rec 2:141-143. doi: 10.3391/bir.2013.2.2.08

Catford J, Jansson R, Nilsson C (2009) Reducing redundancy in invasion ecology by integrating hypotheses into a single theoretical framework. Divers Distrib 15:22-40. doi: $10.1111 / j .1472-4642.2008 .00521 . x$

Cornwell W, Schwilk D, Ackerly D (2006) A trait-based test for habitat filtering: convex hull volume. Ecology 87:1465-1471.

Crocetta F, Agius D, Balistreri P, Bariche M, Bayhan Y, Çakir M, Ciriaco S, Corsini-Foka M, Deidun A, El Zrelli R, Ergüden D, Evans J, Ghelia M, Giavasi M, Kleitou P, Kondylatos G, Lipej L, Mifsud C, Özvarol Y, Pagano A, Portelli P, Poursanidis D, Rabaoui L, Schembri P, Taskin E, Tiralongo F, Zenetos A (2015) New Mediterranean Biodiversity Records (October 2015). Mediterr Mar Sci 16:682-702

Cury PM, Shin YJ, Planque B, Durant JM, Fromentin JM, Kramer-Schadt S, Stenseth NC, Travers M, Grimm V (2008) Ecosystem oceanography for global change in fisheries. Trends Ecol Evol 23:338-346. doi: 10.1016/j.tree.2008.02.005 
Daly BJ, Eckert GL, Long WC (2020) Moulding the ideal crab: implications of phenotypic plasticity for crustacean stock enhancement. ICES J Mar Sci. doi: 10.1093/icesjms/fsaa043

Darnell MZ, Rittschof D, Darnell KM, McDowell RE (2009) Lifetime reproductive potential of female blue crabs Callinectes sapidus in North Carolina, USA. Mar Ecol Prog Ser 394:153163. doi: $10.3354 /$ meps 08295

Davie PJF, Guinot D, Ng PKL (2015) Anatomy and Functional Morphology of Brachyura. In: Castro P, Davie PJF, Guinot D, Schram FR, von Vaupel Klein, JC (eds) Treatise on Zoology - Anatomy, Taxonomy, Biology. The Crustacea. Volume 9C. Decapoda: Brachyura (Part 1). pp 11-163. https://doi.org/10.1163/9789004190832_004

Davis JLD, Young-Williams AC, Aguilar R, Carswell BL, Goodison, MR, Hines, AH, Kramer, MA, Zohar Y, Zmora O (2004) Differences between Hatchery-Raised and Wild Blue Crabs: Implications for Stock Enhancement Potential. Trans Am Fish Soc 133:1-14. doi: $10.1577 / \mathrm{t} 03-004$

DeFur PL, Pease A, Siebelink A, Elfers S (1988) Respiratory responses of blue crabs, Callinectes sapidus, to emersion. Comp Biochem Physiol Part A Physiol 89:97-101

DeRivera CE, Ruiz GM, Hines AH, Jivoff P (2005) Biotic Resistance to Invasion: Native Predator Limits Abundance and Distribution of an Introduced Crab. Ecology 86:3364-3376

Du F, Xu X, Zhang XC, Sui Y, Shao M, Hu L, Shan L (2012) The relationships between aboveground biomass and Voronoi area of coexisting species in an old-field community. Polish J Ecol 60:479-489

Farré M, Tuset VM, Cartes JE, Massutí E, Lombarte A (2016) Depth-related trends in morphological and functional diversity of demersal fish assemblages in the western Mediterranean Sea. Prog Oceanogr 147:22-37. doi: 10.1016/j.pocean.2016.07.006

Ficetola GF, Thuiller W, Miaud C (2007) Prediction and validation of the potential global distribution of a problematic alien invasive species - The American bullfrog. Divers Distrib 13:476-485. doi: 10.1111/j.1472-4642.2007.00377.x

Förster R (1985) Evolutionary trends and ecology of Mesozoic decapod crustaceans. Trans R Soc Edinburgh 76:299-304. doi: 10.1017/S0263593300010518

Froglia C, Speranza S (1993) First record of Dyspanopeus sayi (Smith, 1869) in the Mediterranean Sea (Crustacea: Decapoda: Xanthidae). Quad Ist Ric Pesca Marittima 5:163166 
Fusté X (1988) Crustaceos decapodos de la Bahia de els Alfacs (Delta del Ebro). Inv. Pesq. $52: 617-623$

Galil B (2007) Loss or gain? Invasive aliens and biodiversity in the Mediterranean Sea. Mar pollut bull 55(7-9):314-322. doi: https://doi.org/10.1016/j.marpolbul.2006.11.008

Galil B (2011) The Alien Crustaceans in the Mediterranean Sea: An Historical Review. In: Galil B, Clark P, Carlton J (eds) In the Wrong Place - Alien Marine Crustaceans: Distribution, Biology and Impacts. Invading Nature - Springer Series in Invasion Ecology, 6, pp 377-402

Galil B, Froglia C, Noël P (2002) CIESM atlas of exotic species in the Mediterranean, Volumen 2. Crustaceans: decapods and stomatopods. CIESM Publishers, Monaco

Gehrels H, Knysh KM, Boudreau M, Thériault MH, Courtenay SC, Cox R, Quijón PA (2016) Hide and seek: habitat-mediated interactions between European green crabs and native mud crabs in Atlantic Canada. Mar Biol 163:152. doi: 10.1007/s00227-016-2927-6

González JA, Triay-Portella R, Escribano A, Cuesta JA (2017) Northernmost record of the pantropical portunid crab Cronius ruber in the eastern Atlantic (Canary Islands): natural range extension or human-mediated introduction? Sci Mar 81:81-89. doi: 10.3989/scimar.04551.17b

Grosholz E (2002) Ecological and evolutionary consequences of coastal invasions. Trends Ecol Evol 17:22-27. doi: 10.1016/S0169-5347(01)02358-8

Guillén J, Palanques A (1997) A historical perspective of the morphological evolution in the lower Ebro river. Environ Geol 30:174-180. doi: 10.1007/s002540050144

Halpern BS, Walbridge S, Selkoe KA, Kappel CV, Micheli F, D’Agrosa C, Bruno JF, Casey KS, Ebert C, Fox HE, Fujita R, Heinemann D, Lenihan HS, Madin EMP, Perry MT, Selig ER, Spalding M, Steneck R, Watson R (2008) A Global Map of Human Impact on Marine Ecosystems. Science 319:948-952. doi: 10.1126/science.1149345.

Hammer Ø, Harper DA, Ryan PD (2001) PAST: Paleontological Statistics software package for education and data analysis. Paleontol Electron 4:9 pp

Hampton KR, Hopkins MJ, Mcnamara JC, Thurman CL (2014) Intraspecific variation in carapace morphology among fiddler crabs (Genus Uca) from the Atlantic coast of Brazil. Aquat Biol 20:53-67. doi: 10.3354/ab00545

Harley CDG, Hughes AR, Hultgren KM, Miner BG, Sorte CJB, Thornber CS, Rodriguez LF, Tomaner L, Williams SL (2006) The impacts of climate change in coastal marine systems. 
Ecol Lett 9:228-241. doi: 10.1111/j.1461-0248.2005.00871.x

Harris LG, Tyrrell MC (2001) Changing community states in the Gulf of Maine: Synergism between invaders, overfishing and climate change. Biol Invasions 3:9-21. doi: 10.1023/A:1011487219735

Hartnoll RG (1971) The occurrence, methods and significance of swimming in the Brachyura. Anim Behav 19:34-50. doi: 10.1016/S0003-3472(71)80132-X

Hidalgo M, Rouyer T, Molinero JC, Massutí E, Moranta J, Guijarro B, Stenseth NC (2011) Synergistic effects of fishing-induced demographic changes and climate variation on fish population dynamics. Mar Ecol Prog Ser 426:1-12. doi: 10.3354/meps09077

Hill J, Fowler DL, Van den Avyle MJ (1989) Species Profiles. Life Histories and Environmental Requirements of Coastal Fishes and Invertebrates (Mid-Atlantic). Blue Crab. U.S. Army Corps of Engineers, Vicksburg

Hines AH (1982) Coexistence in a Kelp Forest: Size, Population Dynamics, and Resource Partitioning in a Guild of Spider Crabs (Brachyura, Majidae). Ecol Monogr 52:179-198. doi: $10.2307 / 1942610$

Hoegh-Guldberg O, Bruno JF (2010) The Impact of Climate Change on the World's Marine Ecosystems. Science 328:1523-1528. doi: 10.1080/00330124.2015.1124788

Hopkins MJ, Thurman CL (2010) The geographic structure of morphological variation in eight species of fiddler crabs (Ocypodidae: Genus Uca) from the eastern United States and Mexico. Biol J Linn Soc 100:248-270. doi: 10.1111/j.1095-8312.2010.01402.x

Hughes TP, Baird AH, Bellwood DR, Card M, Connolly SR, Folke C, Grosberg R, HoeghGuldberg O, Jackson JBC, Kleypas J, Lough JM, Marshall P, Nyström M, Palumbi SR, Pandolfi JM, Rosen B, Roughgarden J (2003) Climate change, human impacts, and the resilience of coral reefs. Science 301:929-934. doi: 10.1126/science.1085046

Idaszkin YL, Márquez F, Nocera AC (2013) Habitat-specific shape variation in the carapace of the crab Cyrtograpsus angulatus. J Zool 290:117-126. doi: 10.1111/jzo.12019

Jivoff P, Hines AH, Quackenbush LS (2007) Reproduction biology and embryonic development. In: Kennedy VS, Cronin LE (eds) The Blue Crab: Callinectes sapidus. Maryland Sea Grant College, College Park, Maryland, pp 255-298

Karatayev AY, Burlakova LE, Padilla DK, Mastitsky SE, Olenin S (2009) Invaders are not a random selection of species. Biol Invasions 11:2009-2019. doi: 10.1007/s10530-009-9498-0 
556 Katsanevakis S, Wallentinus I, Leppäkoski E, Çinar ME, Oztürk B, Grabowski M, Golani D, Cardoso AC (2014) Impacts of Invasive Alien Marine Species on Ecosystem Services and Biodiversity: a pan-European Review. Aquat Invasions 9:391-423. doi: 10.3391/ai.2014.9.4.01

Kolar CS, Lodge DM (2001) Progress in invasion biology: predicting invaders. Trends Ecol Evol 16:199-204

Lai JCY, Ng PKL, Davie PJF (2010) A revision of the Portunus pelagicus (Linnaeus, 1758) species complex (Crustacea: Brachyura: Portunidae), with the recognition of four species. Raffles Bull Zool 58:199-237

Lee SY (1995) Cheliped size and structure: the evolution of a multi-functional decapod organ. J Exp Mar Bio Ecol 193:161-176. doi: 10.1016/0022-0981(95)00116-6

Lejeusne C, Latchere O, Petit N, Rico C, Green AJ (2014) Do invaders always perform better? Comparing the response of native and invasive shrimps to temperature and salinity gradients in south-west Spain. Estuar Coast Shelf Sci 136:102-111. doi: 10.1016/j.ecss.2013.11.014

López V, Rodon J (2018) Diagnosi i situació actual del Cranc Blau (Callinectes sapidus) al delta de 1' Ebre. Informe Tècnic Servei de Recursos Marins. Direcció General de Pesca i Afers Marítims, Generalitat de Catalunya, $86 \mathrm{pp}$

MacDonald JA, Roudez R, Glover T, Weis JS (2007) The invasive green crab and Japanese shore crab: Behavioral interactions with a native crab species, the blue crab. Biol Invasions 9:837848. doi: 10.1007/s10530-006-9085-6

Mancinelli G, Carrozzo L, Costantini ML, Rossi L, Marini G, Pinna M (2013) Occurrence of the Atlantic blue crab Callinectes sapidus Rathbun, 1896 in two Mediterranean coastal habitats: Temporary visitor or permanent resident? Estuar Coast Shelf Sci 135:46-56. doi: 10.1016/j.ecss.2013.06.008

Mariappan P, Balasundaram C, Schmitz B (2000) Decapod crustacean chelipeds: An overview. J Biosci 25:301-313. doi: 10.1007/BF02703939

Micu D, Niţă V, Todorova V (2010) First record of Say’s mud crab Dyspanopeus sayi (Brachyura: Xanthoidea: Panopeidae) from the Black Sea. Mar Biodivers Rec 3:1-6. doi: $10.1017 / \mathrm{S} 1755267210000308$

Millikin MR, Williams AB (1984) Synopsis of biological data on blue crab, Callinectes sapidus Rathbun. FAO Fish Synopsis 
Mistri M (2004) Predatory behavior and preference of a successful invader, the mud crab Dyspanopeus sayi (Panopeidae), on its bivalve prey. J Exp Mar Bio Ecol 312:385-398. doi: 10.1016/j.jembe.2004.07.012

Mizzan L (1995) Notes on presence and diffusion of Dyspanopeus sayi (Smith, 1869) (Crustacea, Decapoda, Xanthidae) in the Venetian Lagoon. Boll Mus Civ St Nat Venezia 44:121-129

Nehring S (2011) Invasion History and Success of the American Blue Crab Callinectes sapidus in European and Adjacent Waters. In: Galil B, Clark P, Carlton J (eds) In the Wrong Place Alien Marine Crustaceans: Distribution, Biology and Impacts. Invading Nature - Springer Series in Invasion Ecology, 6: 607-624

Ng PKL (1998) Crabs. In: Carpenter KE, Niem VH (eds) FAO Species Identification Guide for Fishery Purposes. The Living Marine Resources of the Western Central Pacific. Volume 2: Cephalopods, crustaceans, holothurians and sharks. pp 1045-1055

Nizinski MS (2003) Annotated checklist of decapod crustaceans of Atlantic coastal and continental shelf waters of the United States. Proc Biol Soc Washingt 116:96-157

Olesen J (2013) The crustacean carapace: morphology, function, development, and phylogenetic history. In: Watling L, Thiel M (eds) Functional Morphology and Diversity of Crustaceans. The Natural History of the Crustacea. Volume 1. Oxford University Press, Oxford, pp 103139

Parmesan C, Yohe G (2003) A globally coherent fingerprint of climate change impacts across natural systems. Nature 421:37-42. doi: 10.1038/nature01286

Parravicini V, Azzurro E, Kulbicki M, Belmaker J (2015) Niche shift can impair the ability to predict invasion risk in the marine realm: An illustration using Mediterranean fish invaders. Ecol Lett 18:246-253. doi: 10.1111/ele.12401

Pazooki J, Hosseini M, Zadeh AV (2012) The dietary compositions of the blue swimming crab, Portunus segnis (Forskal, 1775) from Persian Gulf, South Iran. World Appl Sci J 20:416422. doi: 10.5829/idosi.wasj.2012.20.03.1969

Perry AL, Low PJ, Ellis JR, Reynolds JD (2005) Climate Change and Distribution Shifts in Marine Fishes. Science 308:1912-1915. doi: 10.1126/science.1111322

Philippart CJM, Anadón R, Danovaro R, Dippner JW, Drinkwater KF, Hawkins SJ, Oguz T, O'Sullivan G, Reid PC (2011) Impacts of climate change on European marine ecosystems: Observations, expectations and indicators. J Exp Mar Bio Ecol 400:52-69. doi: 
10.1016/j.jembe.2011.02.023

Pörtner HO, Farrell P (2008) Physiology and Climate Change. Science 322:690-692. doi: $10.1007 / \mathrm{s} 10502-012-9180-7$

Prager MH, McConaugha JR, Jones CM, Geer PJ (1990) Fecundity of blue crab, Callinectes sapidus, in Chesapeake Bay: biological, statistical and management considerations. Bull Mar Sci 46:170-179

Pyle R, Cronin E (1950) The general anatomy of the blue crab Callinectes sapidus Rathbun. Chesapeake Biological Laboratory Publications 87, 40 pp

R Development Core Team (2017) R: A language and environment for statistical computing. R Foundation for Statistical Computing, Vienna, Austria

Rabaoui L, Arculeo M, Mansour L, Tlig-Zouari S (2015) Occurrence of the lessepsian species Portunus segnis (Crustacea: Decapoda) in the Gulf of Gabes (Tunisia): First record and new information on its biology and ecology. Cah Biol Mar 56:169-175

Reuschel S, Schubart CD (2007) Contrasting genetic diversity with phenotypic diversity in coloration and size in Xantho poressa (Brachyura: Xanthidae), with new results on its ecology. Mar Ecol 28:296-305. doi: 10.1111/j.1439-0485.2006.00139.x

Ricciardi A, Hoopes MF, Marchetti MP, Lockwood JL (2013) Progress toward understanding the ecological impacts of nonnative species. Ecol Monogr 83:263-282. doi: 10.1890/13-0183.1

Rohlf FJ (1999) Shape statistics: Procrustes superimpositions and tangent spaces. J Classif $16: 197-223$

Rohlf FJ (2017a) TPS Dig Version 2.30 and TPS Relative Warps Software. State University of New York at Stony Brook

Rohlf FJ (2017b) TPS Relw Version 1.69 and TPS RelativeWarps Software. State University of New York at Stony Brook

Rohlf FJ (2017c) TpsSmall Version 1.34 and TPS Relative Warps Software. State University of New York at Stony Brook

Rohlf FJ, Slice D (1990) Extensions of the Procrustes method for the optimal superimposition of landmarks. Syst Biol 39:40-59

Rojas-Vélez S, Tavera J, Acero A (2019) Unraveling lionfish invasion: Is Pterois volitans truly a morphologically novel predator in the Caribbean? Biol Invasions 21:1921-1931. doi: $10.1007 / \mathrm{s} 10530-019-01946-6$ 
Rufino MM, Abelló P, Jones DA (2004) Male and female carapace shape differences in Liocarcinus depurator (Decapoda, Brachyura): An application of geometric morphometric analysis to crustaceans. Ital. J. Zool. 71:79-83

Rufino MM, Abelló P, Yule AB (2006) Geographic and gender shape differences in the carapace of Liocarcinus depurator (Brachyura: Portunidae) using geometric morphometrics and the influence of a digitizing method. J Zool 269:458-465. doi: 10.1111/j.14697998.2006.00086.x

Safaie M, Pazooki J, Kiabi B, Shokri MR (2013) Reproductive biology of blue swimming crab, Portunus segnis (Forskal, 1775) in coastal waters of Persian Gulf and Oman Sea, Iran. Iran J Fish Sci 12:430-444

Scholtz G (2014) Evolution of crabs - history and deconstruction of a prime example of convergence. Contrib to Zool 83:87-105

Schubart CD, Guerao G, Abelló P (2012) First record and evidence of an established population of the North American mud crab Dyspanopeus sayi (Brachyura: Heterotremata: Panopeidae) in the western Mediterranean. Sci Mar 76:79-85. doi: 10.3989/scimar.03361.16A

Shea K, Chesson P (2002) Community ecology theory as a framework for biological invasions. Trends Ecol Evol 17:170-176. doi: 10.1016/s0169-5347(02)02495-3

Silva IC, Hawkins SJ, Paula J (2009) A comparison of population differentiation in two shore crab species with contrasting distribution along the Portuguese coast, using two morphological methodologies. Mar Freshw Res 60:833-844

Simberloff D, Martin JL, Genovesi P, Maris V, Wardle DA, Aronson J, Courchamp F, Galil B, García-Berthou E, Pascal M, Pyšek P, Sousa R, Tabacchi E, Vilà M (2013) Impacts of biological invasions: What's what and the way forward. Trends Ecol Evol 28:58-66. doi: 10.1016/j.tree.2012.07.013

Smith SM, Fox RJ, Donelson JM, Head ML, Booth DJ (2016) Predicting range-shift success potential for tropical marine fishes using external morphology. Biol Lett 12: 20160505. doi: $10.1098 / \mathrm{rsbl} .2016 .0505$

Sneddon LU, Huntingford FA, Taylor AC (1997) Weapon size versus body size as a predictor of winning in fights between shore crabs, Carcinus maenas (L.). Behav Ecol Sociobiol 41:237-242

Solé J, Turiel A, Estrada M, Llebot C, Blasco D, Camp J, Delgado M, Fernández-Tejedor M, 
Diogène J (2009) Climatic forcing on hydrography of a Mediterranean bay (Alfacs Bay). Cont Shelf Res 29:1786-1800. doi: 10.1016/j.csr.2009.04.012

Spivak ED, Arévalo E, Cuesta JA, González-Gordillo JI (2010) Population structure and reproductive biology of the stone crab Xantho poressa (Crustacea: Decapoda: Xanthidae) in the 'Corrales de Rota' (south-western Spain), a human-modified intertidal fishing area. J Mar Biol Assoc United Kingdom 90:323-334. doi: 10.1017/S0025315409990592

Stachowicz JJ, Terwin JR, Whitlatch RB, Osman RW (2002) Linking climate change and biological invasions: Ocean warming facilitates nonindigenous species invasions. Proc Natl Acad Sci 99:15497-15500. doi: 10.1073/pnas.242437499

Števčić Z (1971) The main features of brachyuran evolution. Syst Zool 20:331-340. doi: $10.2307 / 2412345$

Streftaris N, Zenetos A (2006) Alien marine species in the Mediterranean - the 100 "worst invasives" and their impact. Mediterr Mar Sci 7:87-118. doi: 10.12681/mms.180

Taylor AC, Atkinson RJA (1991) Respiratory adaptations of aquatic decapod crustaceans and fish to a burrowing mode of life. In: Woakes AJ, Grieshaber MK, Bridges CR (eds) Physiological Strategies for Gas Exchange and Metabolism: Society of Experimental Biology, Seminar Series, Vol. 41. Cambridge University Press, Cambridge, UK, pp 211-234 Thessalou-Legaki M, Aydogan O, Bekas P, Bilge G, Boyaci YO, Brunelli E, Circosta V, Crocetta F, Durucan F, Erdem M, Ergolavou A, Filiz H, Fois F, Gouva E, Kapiris K, Katsanevakis S, Kljajić Z, Konstantinidis E, Konstantinou G, Koutsogiannopoulos D, Lamon S, Mačić V, Mazzette R, Meloni D, Mureddu A, Paschos I, Perdikaris C, Piras F, Poursanidis D, Ramos-Esplá AA, Rosso A, Sordino P, Sperone E, Sterioti A, Taşkin E, Toscano F, Tripepi S, Tsiakkiros L, Zenetos A (2012) New Mediterranean Biodiversity Records (December 2012). Mediterr Mar Sci 13:312-327

Tuset VM, Lombarte A, Bariche M, Maynou F, Azzurro E (2020) Otolith morphological divergences of successful Lessepsian fishes on the Mediterranean coastal waters. Estuar Coast Shelf Sci 236:106631. doi: 10.1016/j.ecss.2020.106631

Ulman A, Ferrario J, Occhipinti-Ambrogi A, Arvanitidis C, Bandi A, Bertolino M, Bogi C, Chatzigeorgiou G,Çiçek BA, Deidun A, Ramos-Esplá A, Koçak C, Lorenti M, MartinezLaiz G, Merlo G, Princisgh E, Scribano G, Marchini A (2017) A massive update of nonindigenous species records in Mediterranean marinas. PeerJ 5: e3954. doi: 
10.7717/peerj.3954

Van Engel W (1958) The blue crab and its fishery in Chesapeake bay. Part 1. Reproduction, early development, growth and migration. Commer Fish Rev 20:6-17

Veas R, Hernández-Miranda E, Quiñones RA (2014) Body shape and burial behavior of the sand crab Emerita analoga (Stimpson 1857) in a reflective to intermediate morphodynamic range of sandy beaches. Mar Biol 161:2345-2357. doi: 10.1007/s00227-014-2510-y

Vermeij GJ (1977) Patterns in Crab Claw Size : The Geography of Crushing. Syst Zool 26:138151

Walther GR, Roques A, Hulme PE, Sykes MT, Pyšek P, Kühn I, Zobel M, Bacher S, Botta-Dukát Z, Bugmann H, Czúcz B, Dauber J, Hickler T, Jarošík V, Kenis M, Klotz S, Minchin D, Moora M, Nentwig W, Ott J, Panov VE, Reineking B, Robinet C, Semenchenko V, Solarz W, Thuiller W, Vilà M, Vohland K, Settele J (2009) Alien species in a warmer world: risks and opportunities. Trends Ecol Evol 24:686-693. doi: 10.1016/j.tree.2009.06.008

Weis JS (2010) The role of behavior in the success of invasive crustaceans. Mar Freshw Behav Physiol 43:83-98. doi: 10.1080/10236244.2010.480838

Wernberg T, Smale DA, Tuya F, Thomsen MS, Langlois TJ, De Bettignies T, Bennett S, Rousseaux CS (2013) An extreme climatic event alters marine ecosystem structure in a global biodiversity hotspot. Nat Clim Chang 3:78-82. doi: 10.1038/nclimate1627

Williams AB (1984) Shrimps, Lobsters, and Crabs of the Atlantic Coast of the Eastern United States, Maine to Florida. Smithsonian Institution Press, Washington DC

Young AC, Johnson EG, Davis JLD, Hines AH, Zmora O, Zohar Y (2008) Do Hatchery-Reared Blue Crabs Differ from Wild Crabs, and Does it Matter? Rev Fish Sci 16:254-261. doi: $10.1080 / 10641260701684122$

Zelditch ML, Swiderski D, Sheets H (2012) Geometric morphometrics for biologists: a primer. Elsevier Academic Press

Zobel M (1997) The relative role of species pools in determining plant species richness: An alternative explanation of species coexistence? Trends Ecol Evol 12:266-269. doi: 10.1016/S0169-5347(97)01096-3 


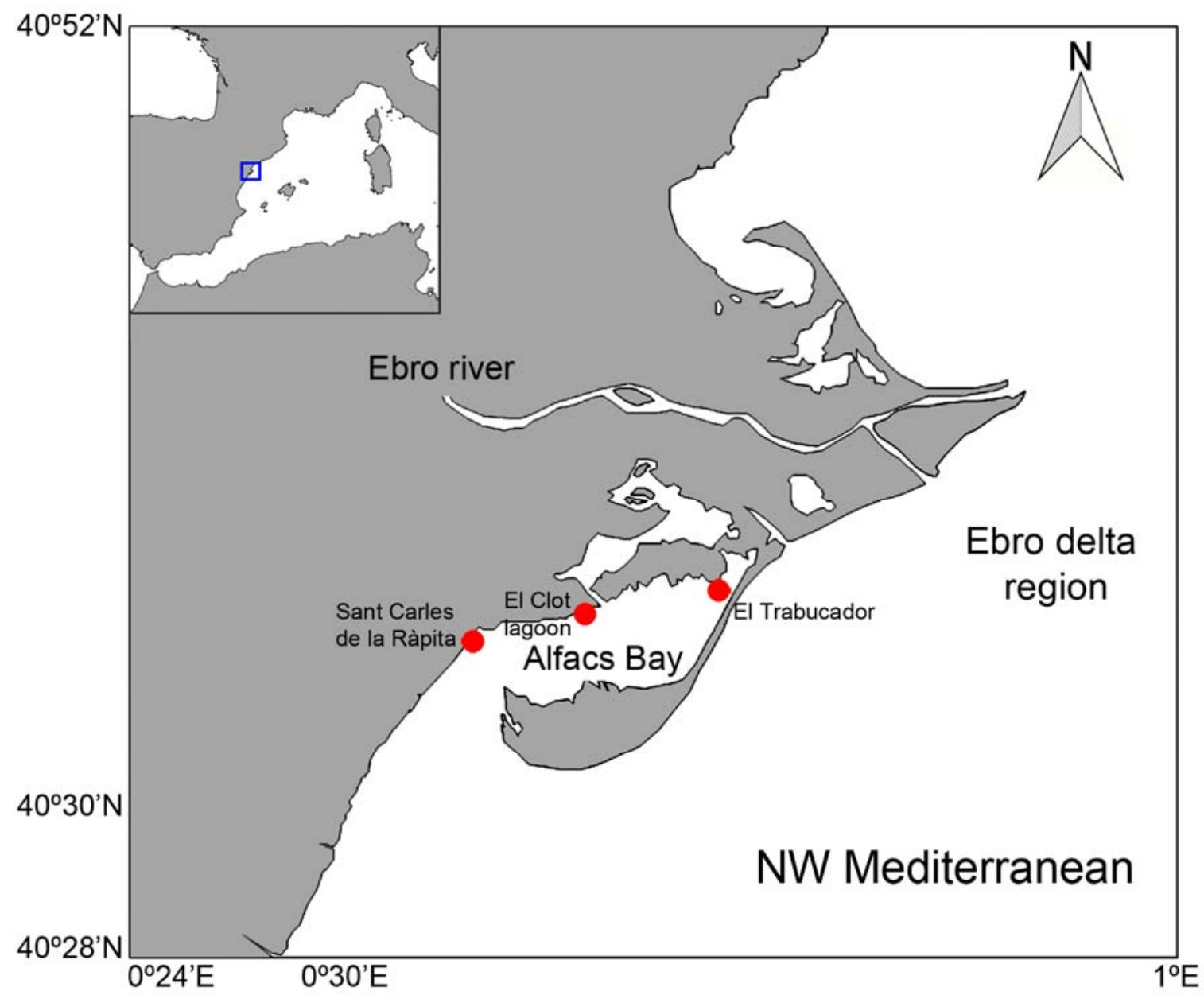

743 Fig. 1 Map of the study area (Alfacs bay, Ebro Delta region, NW Mediterranean) and specific 744 areas where non-native species were collected. Adapted from Schubart et al. 2012 


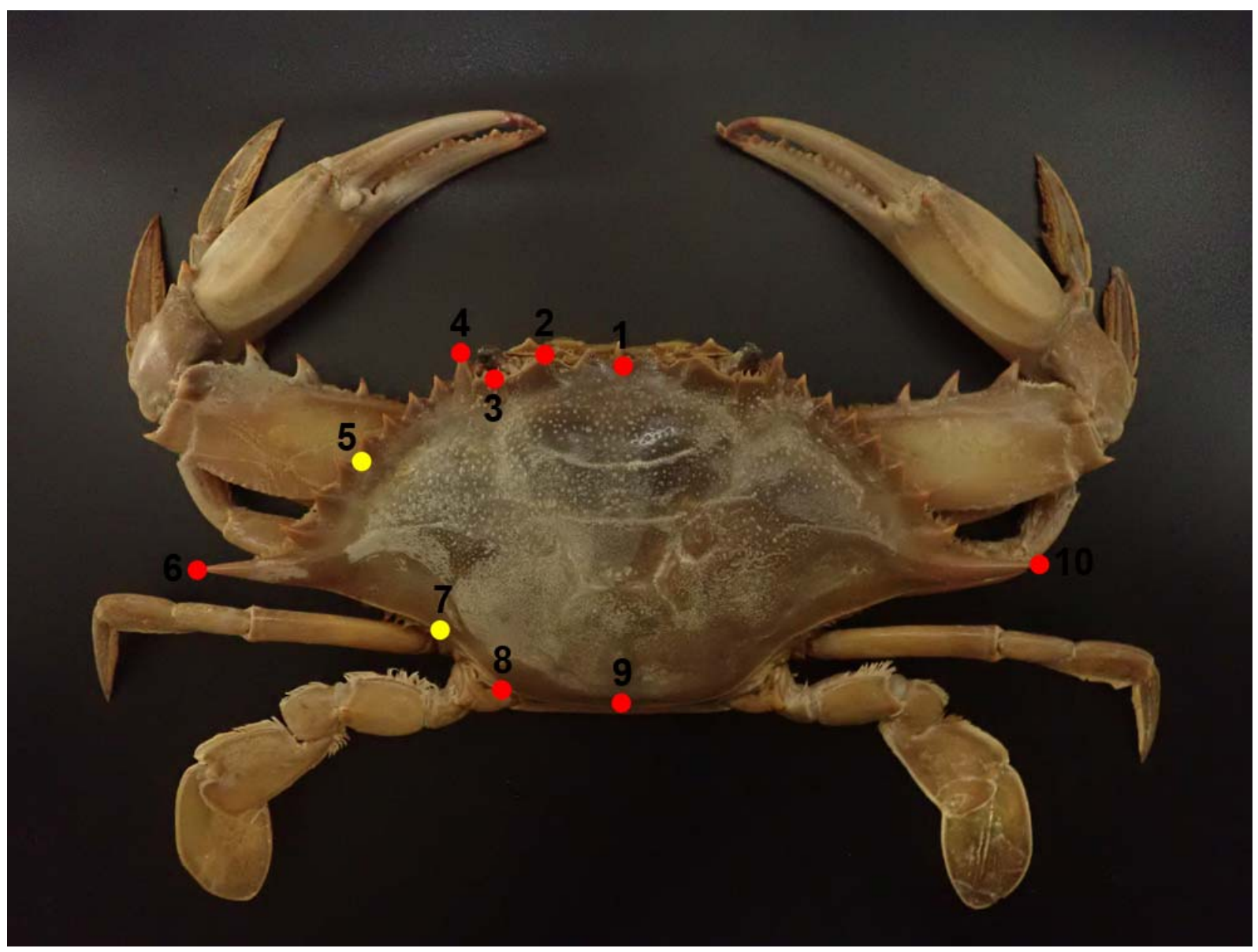

Fig. 2 Scheme of the landmarks ( $N=8$, red points) and semilandmarks ( $N=2$, yellow points) used for description of the dorsal carapace shape of crabs. The definition of the meaning of landmarks and semilandmarks is detailed in Supplementary material, Table S1. The specimen of the image is an individual of Callinectes sapidus from the Biological Reference Collections (CBR) of the Marine Science Institute (ICM-CSIC) of Barcelona

758

759 
(a)

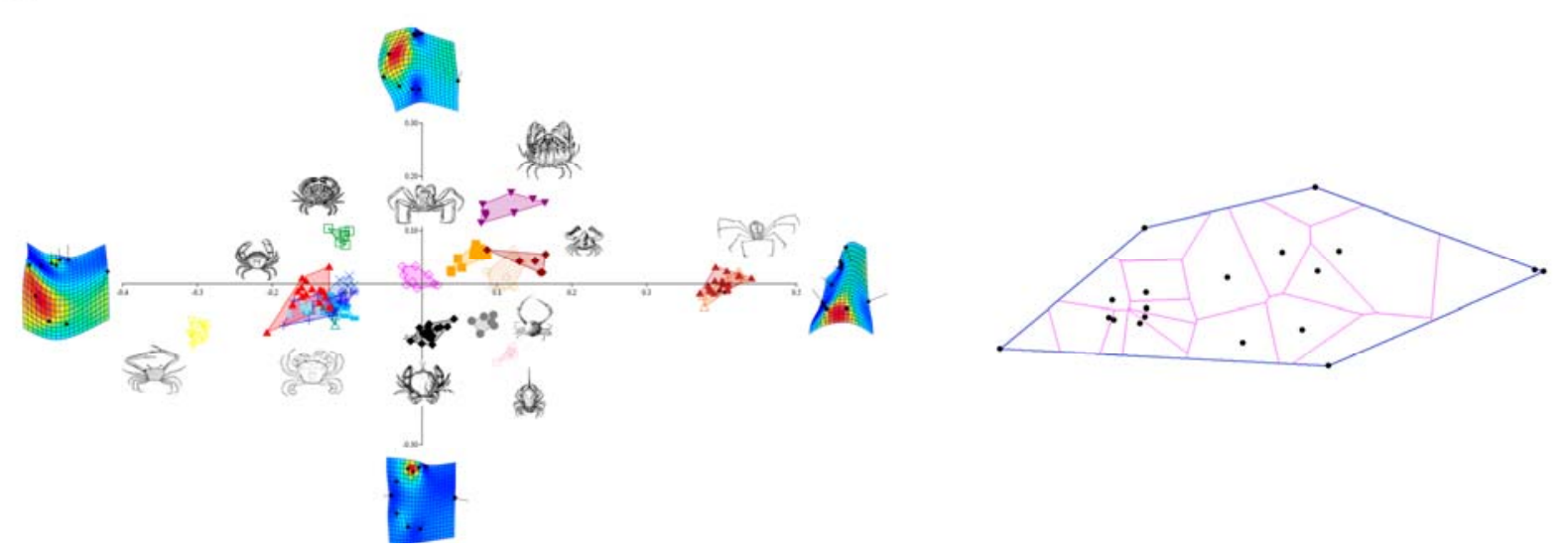

(b)
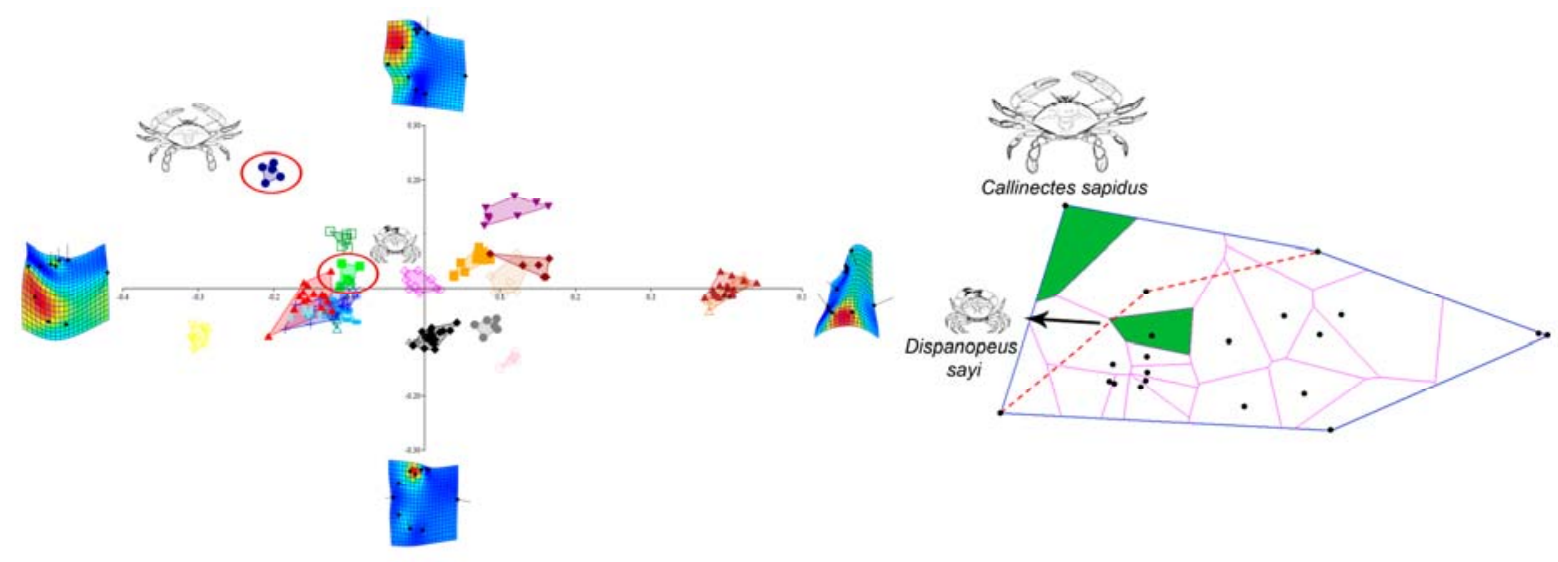

(c)
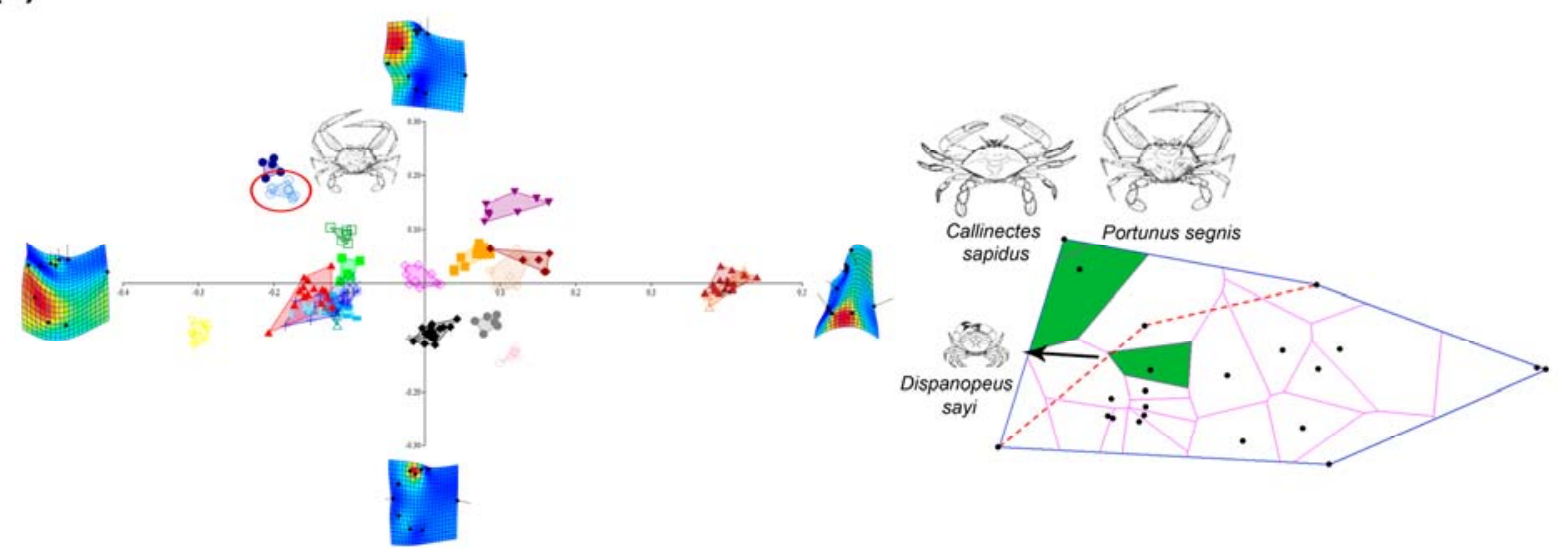

- Atelecyclus rotundatus Corystes cassivelaunus + Liocarcinus depurator Maja crispata Portunus segnis

$\triangle$ Brachynotus sexdentatus $\circ$ Dromia personata * Liocarcinus navigator $=$ Medorippe lanata $\square$ Xantho poressa

- Calappa granulata Dyspanopeus sayi X Liocarcinus vernalís " Necora puber

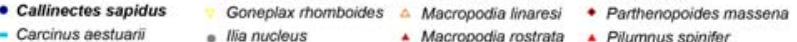


765 Fig. 3 Two-dimensional (RW1-RW2) morphospace representations and Voronoi polygons 766 representation of the a native (NCC), b current (CCC) and $\mathbf{c}$ future crab community (FCC) of 767 Alfacs Bay (Ebro Delta, NW Mediterranean). In the morphospaces, the different convex hulls 768 enclose all specimens of each species, and the color range of symbols is related with the 769 taxonomical similarity (superfamily) of species. Deformation grids indicating the shape variation 770 along the axes and a draw of most representative species are also provided. The position of the 771 non-native species (in bold in legend) in CCC and FCC is highlighted by a red circle. In the 772 Voronoi polygons representation, the position and occupied area by the non-native species is 773 colored in green. The red dashed line represents the original outline of the native morphospace, 774 underlying the increase of the morphological space produced by the non-native species 


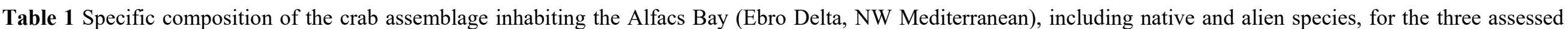

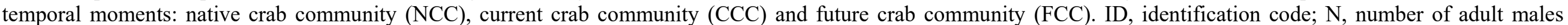

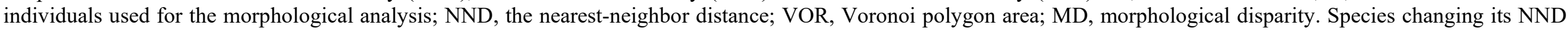
or VOR by invasion of new crabs are marked in bold. The taxonomical classification (superfamily) of each species is provided

\begin{tabular}{|c|c|c|c|c|c|c|c|c|c|c|c|c|c|}
\hline \multirow[t]{2}{*}{ Origin } & \multirow[t]{2}{*}{ Superfamily } & \multirow[t]{2}{*}{ Species } & \multirow[t]{2}{*}{ ID } & \multirow[t]{2}{*}{$\mathrm{N}$} & \multicolumn{3}{|c|}{$\begin{array}{l}\text { Native Crab Community } \\
\text { (NCC) }\end{array}$} & \multicolumn{3}{|c|}{$\begin{array}{c}\text { Current Crab Community } \\
\text { (CCC) }\end{array}$} & \multicolumn{3}{|c|}{$\begin{array}{l}\text { Future Crab Community } \\
\text { (FCC) }\end{array}$} \\
\hline & & & & & NND (ID) & VOR & MD & NND (ID) & VOR & MD & NND (ID) & VOR & MD \\
\hline \multirow[t]{19}{*}{ Native } & Calappoidea & Calappa granulata & 3 & 8 & $0.099(17)$ & 5883.0 & 0.0002 & $0.099(17)$ & 9637.0 & 0.0002 & $0.099(17)$ & 9637.0 & 0.0002 \\
\hline & Cancroidea & Atelecyclus rotundatus & 1 & 19 & $0.077(10)$ & 12375.0 & 0.0009 & $0.077(10)$ & 12375.0 & 0.0009 & $0.077(10)$ & 12375.0 & 0.0009 \\
\hline & Corystoidea & Corystes cassivelaunus & 6 & 6 & $0.068(10)$ & 9230.0 & 0.0004 & $0.068(10)$ & 9230.0 & 0.0004 & $0.068(10)$ & 9230.0 & 0.0004 \\
\hline & Dorippoidea & Medorippe lanata & 17 & 14 & $0.057(16)$ & 13853.0 & 0.0013 & $0.057(16)$ & 15262.0 & 0.0013 & $0.057(16)$ & 15262.0 & 0.0013 \\
\hline & Dromioidea & Dromia personata & 7 & 9 & $0.084(17)$ & 18862.5 & 0.0005 & $0.084(17)$ & 18659.0 & 0.0005 & $0.084(17)$ & 18659.0 & 0.0005 \\
\hline & Goneplacoidea & Goneplax rhomboides & 9 & 9 & $0.150(18)$ & 3681.1 & 0.0009 & $0.150(18)$ & 8575.5 & 0.0009 & $0.150(18)$ & 8559.5 & 0.0009 \\
\hline & Grapsoidea & Brachynotus sexdentatus & 2 & 5 & $0.010(5)$ & 4986.6 & 0.0011 & $0.010(5)$ & 4986.6 & 0.0011 & $0.010(5)$ & 4986.6 & 0.0011 \\
\hline & Leucosioidea & Ilia nucleus & 10 & 6 & $0.067(6)$ & 11609.5 & 0.0013 & $0.067(6)$ & 11609.5 & 0.0013 & $0.067(6)$ & 11609.5 & 0.0013 \\
\hline & Majoidea & Macropodia linaresi & 14 & 7 & $0.006(15)$ & 1.2 & 0.0042 & $0.006(15)$ & 1.2 & 0.0042 & $0.006(15)$ & 1.2 & 0.0042 \\
\hline & Majoidea & Macropodia rostrata & 15 & 16 & $0.006(14)$ & 14097.5 & 0.0018 & $0.006(14)$ & 14097.5 & 0.0018 & $0.006(14)$ & 14097.5 & 0.0018 \\
\hline & Majoidea & Maja crispate & 16 & 7 & $0.039(19)$ & 8682.0 & 0.0027 & $0.039(19)$ & 8682.0 & 0.0027 & $0.039(19)$ & 8682.0 & 0.0027 \\
\hline & Parthenopoidea & Parthenopoides massena & 19 & 6 & $0.039(16)$ & 30054.5 & 0.0009 & $0.039(16)$ & 30054.5 & 0.0009 & $0.039(16)$ & 30054.5 & 0.0009 \\
\hline & Pilumnoidea & Pilumnus spinifer & 20 & 15 & $0.028(18)$ & 6521.5 & 0.0017 & $0.028(18)$ & 16642.0 & 0.0017 & $0.028(18)$ & 15056.8 & 0.0017 \\
\hline & Portunoidea & Carcinus aestuarii & 5 & 7 & $0.011(2)$ & 3182.3 & 0.0008 & $0.011(2)$ & 3182.3 & 0.0008 & $0.011(2)$ & 3182.3 & 0.0008 \\
\hline & Portunoidea & Liocarcinus navigator & 12 & 7 & $0.016(5)$ & 2361.2 & 0.0007 & $0.016(5)$ & 2361.2 & 0.0007 & $0.016(5)$ & 2361.2 & 0.0007 \\
\hline & Portunoidea & Liocarcinus depurator & 11 & 10 & $0.018(18)$ & 2913.7 & 0.0024 & $0.018(18)$ & 2913.7 & 0.0024 & $0.018(18)$ & 2913.7 & 0.0024 \\
\hline & Portunoidea & Liocarcinus vernalis & 13 & 7 & $0.023(12)$ & 7412.0 & 0.0003 & $0.023(12)$ & 2887.1 & 0.0003 & $0.023(12)$ & 2887.1 & 0.0003 \\
\hline & Portunoidea & Necora puber & 18 & 6 & $0.018(11)$ & 7850.8 & 0.0004 & $0.018(11)$ & 8015.3 & 0.0004 & $0.018(11)$ & 8015.3 & 0.0004 \\
\hline & Xanthoidea & Xantho poressa & 22 & 6 & $0.098(13)$ & 7671.5 & 0.0018 & $0.067(8)$ & 33399.5 & 0.0018 & $0.067(8)$ & 27427.0 & 0.0018 \\
\hline \multirow[t]{3}{*}{ Non-native } & Portunoidea & Callinectes sapidus & 4 & 5 & - & - & - & $0.1579(22)$ & 12332.5 & 0.0012 & $0.0486(4)$ & 830.4 & 0.0012 \\
\hline & Xanthoidea & Dyspanopeus sayi & 8 & 5 & - & - & - & $0.0322(13)$ & 7808.0 & 0.0002 & $0.0322(13)$ & 7808.0 & 0.0002 \\
\hline & Portunoidea & Portunus segnis & 21 & 9 & - & - & - & - & - & - & $0.0486(4)$ & 18746.5 & 0.0004 \\
\hline
\end{tabular}


Table S1 Description of the meaning of landmarks and semilandmarks (shown in Fig. 2) used to characterize the dorsal shape of the carapace of the analyzed brachyuran crabs. The references of the consulted bibliography to define the landmarks and semilandmarks are provided

\begin{tabular}{lll}
\hline \# point & Type of point & Definition \\
\hline 1 & Landmark & Middle point of the outer frontal margin of the carapace
\end{tabular}

2 Landmark Inner tip of the orbital depression

3 Landmark Deepest point of the orbital depression

4 Landmark Intersection of anterior and anterolateral margin of the carapace, or outer tip of the orbital depression

5 Semilandmark Middle point along the anterolateral margin of the carapace between landmark 4 and 6

$6 \quad$ Landmark

Semilandmark

Intersection between the anterolateral and posterolateral margin of the carapace, or tip of the last anterolateral spine

Landmark landmark 6 and 8 carapace

$9 \quad$ Landmark

Middle point of the outer posterior margin of the carapace

\section{Bibliography used}

Rufino et al. 2006, Sanchez et al. 2013, Alencar et al. 2014, Duarte et al. 2014, Torres et al. 2014

Idazskin et al. 2013, Sanchez et al. 2013, Duarte et al. 2014, Torres et al. 2014

Idazskin et al. 2013, Sanchez et al. 2013, Silva et al. 2014

Rufino et al. 2006, Idazskin et al. 2013, Alencar et al. 2014, Duarte et al. 2014, Silva et al. 2014, Torres et al. 2014, Hopkins and Thurman 2010

Rufino et al. 2006, Idazskin et al. 2013, Sanchez et al. 2013, Silva et al. 2014, Torres et al. 2014

Rufino et al. 2006, Sánchez et al. 2013, Alencar et al. 2014, Duarte et al. 2014, Hopkins and Thurman 2010

Hopkins and Thurman 2010, Idazskin et al. 2013, Sanchez et al. 2013, Torres et al. 2014

Rufino et al. 2006, Hopkins and Thurman 2010, Sanchez et al. 2013, Silva et al. 2014, Torres et al. 2014

Rufino et al. 2006, Hopkins and Thurman 2010, Sanchez et al. 2013, Alencar et al. 2014, Duarte et al. 2014, Silva et al. 2014, Torres et al. 2014

Rufino et al. 2006, Hopkins and Thurman 2010, Idazskin et al. 2013, Sanchez et al. 2013, Silva et al. 2014 


\section{References}

Alencar CERD, Lima-Filho PA, Molina WF, Freire FAM (2014) Sexual shape dimorphism of the mangrove crab Ucides cordatus (Linnaeus, 1763) (Decapoda, Ucididae) accessed through geometric morphometric. Sci World J 2014:206168. doi: 10.1155/2014/206168

Duarte RC, Ré A, Flores AAV, Queiroga H (2014) Conspecific cues affect stage-specific molting frequency, survival, and claw morphology of early juvenile stages of the shore crab Carcinus maenas. Hydrobiologia 724:55-66. doi: 10.1007/s10750-013-1712-5

Hopkins MJ, Thurman CL (2010) The geographic structure of morphological variation in eight species of fiddler crabs (Ocypodidae: genus Uca) from the eastern United States and Mexico. Biol J Linn Soc 100:248-270

Idaszkin YL, Márquez F, Nocera AC (2013) Habitat-specific shape variation in the carapace of the crab Cyrtograpsus angulatus. J Zool 290:117-126

Rufino MM, Abelló P, Yule AB (2006) Geographic and gender shape differences in the carapace of Liocarcinus depurator (Brachyura: Portunidae) using geometric morphometrics and the influence of a digitizing method. $\mathrm{J}$ Zool 269:458-465. doi: 10.1111/j.14697998.2006.00086.x

Sanchez MLS, Gorospe JG, Gorospe JN, Torres MAJ, Demayo CG (2013) Describing geographic differences in carapace shape in the blue swimming crab Portunus pelagicus from Mindanao Bays, Philippines. AACL Bioflux 6:622-634

Silva IC, Alves MJ, Paula J, Hawkins SJ (2014) Population differentiation of the shore crab Carcinus maenas (Brachyura: Portunidae) on the southwest English coast based on genetic and morphometric analyses. Sci Mar 74(3):435-444

Torres MV, Collins PA, Giri F (2014) Morphological variation of freshwater crabs Zilchiopsis collastinensis and Trichodactylus borellianus (Decapoda, Trichodactylidae) among localities from the middle Paraná River basin during different hydrological periods. ZooKeys 457:171-186 